\title{
Proteomic Analysis of Etiolated Juvenile Tetraploid Robinia pseudoacacia Branches during Different Cutting Periods
}

\author{
Nan Lu ${ }^{1, \dagger}$, Zhaohe Xu ${ }^{2, \dagger}$, Bingnan Meng ${ }^{1,3, \dagger}$, Yuhan Sun ${ }^{1}$, Jiangtao Zhang ${ }^{4}$, Shaoming Wang ${ }^{5}$ \\ and $\mathrm{Yun} \mathrm{Li}^{1}{ }^{1, *}$
}

1 National Engineering Laboratory for Tree Breeding, Key Laboratory of Genetics and Breeding in Forest Trees and Ornamental Plants, Ministry of Education, College of Biological Sciences and Technology, Beijing Forestry University, Beijing 100083, China; E-Mails: ln890110@gmail.com (N.L.); mengbn80@gmail.com (B.M.); syh831008@gmail.com (Y.S.)

2 Key Laboratory for Silviculture and Conservation, Ministry of Education, Beijing Forestry University, Beijing 100083, China; E-Mail: xuzhaohecn@gmail.com

3 Beijing Municipal Bureau of Landscaping, Beijing 100029, China

4 Henan Academy of Forestry Science, Zhengzhou 450008, Henan, China;

E-Mail: zhjt5966@gmail.com

5 The State-Owned Luoning County Lv Cun Forest Farm, Luoning 471711, Henan, China; E-Mail: wangshaoming1969@gmail.com

$\dagger$ These authors contributed equally to this work.

* Author to whom correspondence should be addressed; E-Mail: yunli63@gmail.com; Tel./Fax: +86-10-6233-6094.

Received: 17 December 2013; in revised form: 31 March 2014 / Accepted: 2 April 2014 / Published: 21 April 2014

\begin{abstract}
The propagation of hard-branch cuttings of tetraploid Robinia pseudoacacia (black locust) is restricted by the low rooting rate; however, etiolated juvenile tetraploid black locust branches result in a significantly higher rooting rate of cuttings compared with non-etiolated juvenile tetraploid branches. To identify proteins that influence the juvenile tetraploid branch rooting process, two-dimensional electrophoresis (2-DE) and matrix-assisted laser desorption/ionization time-of-flight/time-of-flight mass spectra (MALDI-TOF/TOF-MS) were used to analyze proteomic differences in the phloem of tetraploid $R$. pseudoacacia etiolated and non-etiolated juvenile branches during different cutting periods. A total of 58 protein spots differed in expression level, and 16 protein
\end{abstract}


spots were only expressed in etiolated branches or non-etiolated ones. A total of 40 highly expressed protein spots were identified by mass spectrometry, 14 of which were accurately retrieved. They include nucleoglucoprotein metabolic proteins, signaling proteins, lignin synthesis proteins and phyllochlorin. These results help to reveal the mechanism of juvenile tetraploid $R$. pseudoacacia etiolated branch rooting and provide a valuable reference for the improvement of tetraploid $R$. pseudoacacia cutting techniques.

Keywords: tetraploid Robinia pseudoacacia; etiolated juvenile branch; cutting; proteomics

\section{Introduction}

Compared to normal diploid Robinia pseudoacacia, tetraploid $R$. pseudoacacia clones have a significantly higher yield with large leaves and a high leaf protein content; moreover, they are polyanthous and long blossoming and suitable for feeding and beekeeping. Recent studies have shown that tetraploid $R$. pseudoacacia are fast-growing and able to tolerate harsh environments, including salt and drought; thus, they are widely planted for soil and water conservation, environmental improvement, wind attenuation and sand fixation. Additionally, they have good ecological and economic benefits and can be used in the development of stockbreeding on plains and mountains, among other aspects [1,2].

Because of the high seedling abortion rate and the desire to maintain valuable clonal traits, efficient asexual reproduction methods for tetraploid $R$. pseudoacacia propagation are imperative. Traditional asexual reproduction methods mainly include root cutting, branch cutting, tissue culture and grafting. In China, many labs have successfully established a tissue culture system for tetraploid R. pseudoacacia. By using root segments after sand storage treatment in winter, Dong [3] obtained clonal seedlings with a relatively high survival ratio. As for grafting, Shang [4] obtained a 90\% survival ratio through cleft grafts.

However, these methods have their limitations in terms of production. Root cuttings hurt the root system of mother trees, and the number of seedlings is restricted by mother trees. Tissue culture requires a significant monetary investment and professional techniques; thus, the production cost is very high. Grafting has a longer propagation cycle, usually requiring at least one year to culture rootstocks, and because of the higher growth rate of scions it easily suffers wind-breakage and out-of-line forestems during the graft seedling growing period.

Compared with other asexual propagation methods, branch cutting has several advantages, including being a rich source of branches, harmless to the mother tree, and requiring little monetary investment. By establishing a cutting orchard, we can obtain a number of cutting slips outside of the growing season without hurting the mother tree [1,2]. However, the rooting rate of tetraploid R. pseudoacacia hard-branch cuttings using traditional techniques is only 4\% [5]. Improvements to cutting technology could improve the rooting rate dramatically [6]. Taking advantage of etiolated (causing new buds or juvenile branches to develop without chlorophyll by growing without exposure to sunlight before cutting from the mother tree) juvenile branches as cutting materials is a common way to improve cutting rooting rates and has beneficial effects on the rooting of avocado [7], 
apples [8], maples [9] and other plants. Etiolation not only restrains the production of materials that hinder the rooting process, enhancing the activity of endogenous hormones, it also slows down the lignification of cut slips [10]. In a previous study on the physiology and biochemistry of juvenile tetraploid $R$. pseudoacacia branches, we found that regulation of the level of endogenous hormones and oxidase activity promoted the rooting of etiolated branches [11]; however, this study did not elucidate the mechanism of etiolated juvenile branch rooting.

Proteomics is an effective way to study the mechanism of rooting. Using proteomics, Konishi et al. [12] found that increases in fructose-bisphosphate aldolase activity may play an important role in gibberellic acid-induced root growth. Proteomic studies of mutated Arabidopsis thaliana also helped to elucidate the rooting mechanism [13]. To further study the mechanism of tetraploid $R$. pseudoacacia juvenile branch rooting, we sought to identify proteins that influence the rooting process.

We hypothesize that perhaps the rooting improvement of etiolated juvenile branch was due to the regulation of the expression level of some rooting associated proteins or there are some proteins that promote the rooting of etiolated juvenile branch exist. Therefore, it is necessary to determine differences between proteins in etiolated and non-etiolated juvenile branch during the rooting periods. Since there was no previous study examining proteome levels during the tetraploid $R$. pseudoacacia etiolated juvenile branch cutting period, and no data on this topic are currently available in the literature. Therefore, this study can help us to better understand the mechanism of juvenile branch rooting and provide a reference for improving the cutting technology for tetraploid $R$. pseudoacacia juvenile branches.

\section{Results}

\subsection{Comparative Protein Profiles of Non-Etiolated and Etiolated Juvenile Branch Cuttings during Different Rooting Periods}

All proteins were detected on Coomassie brilliant blue (CBB)-stained gels. The identified spots corresponded to proteins expressed in different periods. Spots of non-etiolated samples were chosen as controls. On day 0 , four proteins were up-regulated, while seven were down-regulated, four spots were not present and one spot was only present in the etiolated samples, compared with non-etiolated samples. On day 3, there were nine spots up-regulated spots, six spots down-regulated spots, three protein spots were not present and there were two unique spots. On day 9, five spots were up-regulated, and seven spots changed in the opposite way, five spots disappeared and one spots only expressed in etiolated samples. In total, 38 protein spots were differentially expressed and 16 spots were only expressed during certain periods in non-etiolated and etiolated branches.

To accurately assess the proteomic changes, spot volume differences of more than two-fold between two identical spots were defined as significant. Significantly differentially expressed spots were subjected to matrix-assisted laser desorption/ionization time-of-flight/time-of-flight mass spectra (MALDI-TOF/TOF-MS) to confirm their identity and function. 


\subsection{Matrix-Assisted Laser Desorption/Ionization Time-of-Flight/Time-of-Flight Mass Spectra} (MALDI-TOF/TOF-MS) Identification of Etiolation-Responsive Proteins

Forty proteins from the differentially expressed spots between the non-etiolated and etiolated samples were arbitrarily selected from the gels and subjected to MALDI-TOF/TOF-MS. Thirty-three proteins were successfully identified. Among the identified proteins, 14 were identified, while 19 were hypothetical proteins or predicted proteins (Figure 1). The identified proteins are listed in Table 1. The fourteen proteins include ribosomal proteins, metabolic proteins, lignin synthesis proteins and chlorophyll proteins.

Figure 1. Representative two-dimensional electrophoresis (2-DE) gels of rooting of etiolated juvenile tetraploid Robinia pseudoacacia branches after (A) day 0; (B) day 3; and (C) day 9. Representative 2-DE gels of rooting of non-etiolated juvenile tetraploid Robinia pseudoacacia branches after (D) day 0; (E) day 3; and (F) day 9.
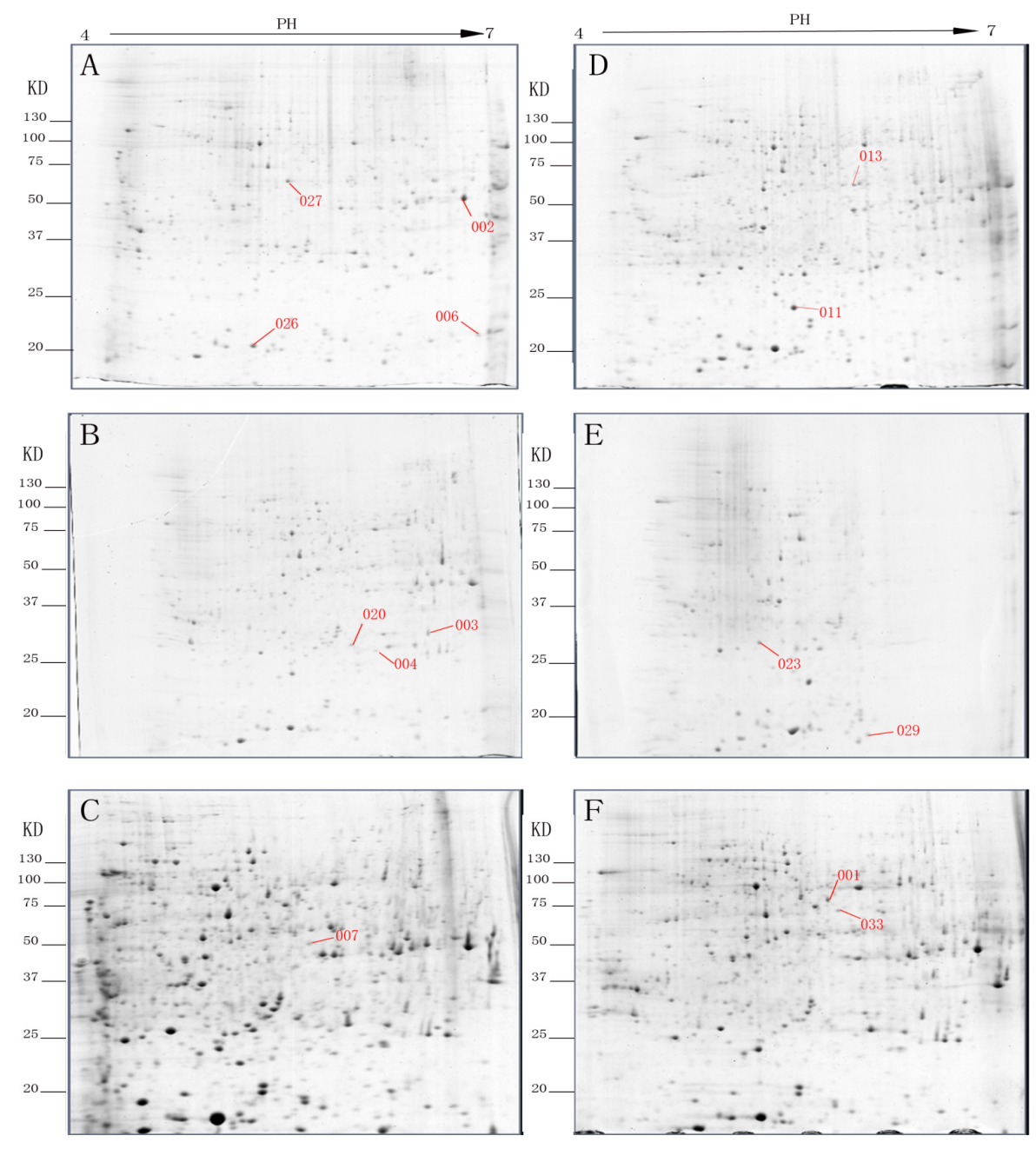

The identified spots (Figure 1) correspond to proteins related to energy, carbohydrate metabolism and photosynthesis. Compared to the non-etiolated branches, seven proteins were up-regulated (spots 002, 003, 004, 006, 020, 026 and 027) and two were down-regulated (spots 001 and 029). One spot was only expressed in etiolated branches (spot 007) while the rest were not present (spots 011,013,023 and 033) in the etiolated branches. 
Table 1. Protein identification through matrix-assisted laser desorption/ionization time-of-flight/time-of-flight mass spectra (MALDI-TOF/TOF-MS).

\begin{tabular}{|c|c|c|c|c|c|c|}
\hline $\begin{array}{l}\text { Protein } \\
\text { ID }\end{array}$ & Accession No. & Description & Score & $\begin{array}{l}\text { SC } \\
(\%)\end{array}$ & $\begin{array}{r}\text { Theoretical } \\
M_{\mathrm{r}}(\mathrm{kDa}) / \mathrm{pI}\end{array}$ & $\begin{array}{c}\text { Observed } \\
M_{\mathrm{r}}(\mathrm{kDa}) / \mathrm{pI}\end{array}$ \\
\hline 001 & gi|116061758 & Putative RNA-binding protein & 92 & 28 & $72.4 / 8.51$ & $78.3 / 5.26$ \\
\hline 002 & gi|168009419 & Methylmalonate-semialdehyde dehydrogenase (MM-ALDH) & 74 & 17 & $61.5 / 8.51$ & $57.1 / 6.33$ \\
\hline 003 & gi|108864006 & $\begin{array}{l}\text { Signal recognition particle } 54 \mathrm{kDa} \text { protein, chloroplast precursor, putative, } \\
\text { expressed [Oryza sativa (japonica cultivar-group)] }\end{array}$ & 80 & 19 & $53.3 / 9.37$ & $38.8 / 6.14$ \\
\hline 004 & gi $\mid 60650116$ & Actin $[$ Pyrus communis $]$ & 106 & 28 & $38.4 / 5.47$ & $28.6 / 5.91$ \\
\hline 005 & gi|242080859 & Hypothetical protein SORBIDRAFT_07g005770 [Sorghum bicolor] & 82 & 21 & $71.8 / 6.17$ & $65.8 / 5.43$ \\
\hline 006 & gi|121761863 & Ribosomal protein S4 [Plagiomnium cf. tezukae Wyatt 1808] & 83 & 12 & $23.5 / 10.39$ & $23.88 / 6.61$ \\
\hline 007 & gi|42521309 & Enolase [Glycine $\max ]$ & 87 & 15 & $47.7 / 5.31$ & $52.2 / 5.05$ \\
\hline 008 & gi|152143640 & $\begin{array}{l}\text { Chloroplast photosynthetic water oxidation complex } 33 \mathrm{kDa} \text { subunit precursor } \\
\qquad \text { [Morus nigra] }\end{array}$ & 78 & 16 & $28.2 / 5.48$ & $35.2 / 5.84$ \\
\hline 009 & gi|242080859 & Hypothetical protein SORBIDRAFT_07g005770 [Sorghum bicolor] & 82 & 21 & $71.8 / 6.17$ & $75.4 / 5.88$ \\
\hline 010 & gi|270306046 & Unnamed protein product [Vitis vinifera] & 98 & 16 & $43.2 / 9.36$ & $50.3 / 5.43$ \\
\hline 011 & gi|67079128 & $\begin{array}{c}\text { Ribulose-1,5-bisphosphatecarboxylase/oxygenase large subunit } \\
\text { [Chasmanthium latifolium] }\end{array}$ & 90 & 14 & $25.2 / 5.82$ & $24.5 / 5.52$ \\
\hline 012 & gi|255559120 & Cytosolic purine 5-nucleotidase, putative [Ricinus communis] & 82 & 12 & $62.7 / 6.67$ & $72.1 / 6.22$ \\
\hline 013 & gi|166156335 & Maturase K [Protea neriifolia $]$ & 83 & 17 & $60.0 / 9.51$ & $64.2 / 5.83$ \\
\hline 014 & gi|147814811 & Hypothetical protein [Vitis vinifera] & 104 & 25 & $78.8 / 6.23$ & $85.7 / 6.54$ \\
\hline 015 & gi|242081717 & Hypothetical protein SORBIDRAFT_07g022905 [Sorghum bicolor] & 73 & 8 & $21.0 / 5.73$ & $19.2 / 6.47$ \\
\hline 016 & gi|168044879 & Predicted protein [Physcomitrella patens subsp. patens] & 74 & 9 & $38.8 / 9.45$ & $40.8 / 5.43$ \\
\hline 017 & gi|13928452 & 14-3-3 Protein [Vigna angularis] & 108 & 21 & $29.2 / 4.66$ & $35.2 / 5.21$ \\
\hline 018 & gi|255559120 & Cytosolic purine 5-nucleotidase, putative [Ricinus communis] & 82 & 12 & $62.7 / 6.67$ & $72.6 / 6.08$ \\
\hline 019 & gi|224141801 & Predicted protein [Populus trichocarpa] & 84 & 18 & $60.9 / 7.04$ & $68.2 / 5.92$ \\
\hline 020 & gi|224055984 & Actin 1 [Populus trichocarpa] & 130 & 26 & $41.7 / 5.31$ & $33.7 / 5.82$ \\
\hline 021 & gi|225448323 & Predicted: hypothetical protein [Vitis vinifera] & 126 & 28 & $41.6 / 5.31$ & $35.2 / 6.05$ \\
\hline 022 & gi|125563066 & Hypothetical protein OsI_30711 [Oryza sativa Indica Group] & 78 & 25 & $88.7 / 9.13$ & $85.5 / 5.67$ \\
\hline
\end{tabular}


Table 1. Cont

\begin{tabular}{|c|c|c|c|c|c|c|}
\hline $\begin{array}{c}\text { Protein } \\
\text { ID }\end{array}$ & Accession No. & Description & Score & $\begin{array}{c}\text { SC } \\
(\%) \\
\end{array}$ & $\begin{array}{l}\text { Theoretical } \\
M_{\mathrm{r}}(\mathrm{kDa}) / \mathrm{pI}\end{array}$ & $\begin{array}{c}\text { Observed } \\
M_{\mathrm{r}}(\mathrm{kDa}) / \mathrm{pI} \\
\end{array}$ \\
\hline 023 & gi|162463414 & Golgi associated protein se-wap4 [Zea mays] & 88 & 18 & $41.2 / 5.75$ & $32.8 / 5.30$ \\
\hline 024 & gi|255554359 & Conserved hypothetical protein [Ricinus communis] & 74 & 14 & $60.7 / 6.12$ & $68.4 / 5.76$ \\
\hline 025 & gi|225437076 & Predicted: hypothetical protein isoform [Vitis vinifera] & 82 & 16 & $63.9 / 7.18$ & $71.4 / 6.37$ \\
\hline 026 & gi|194466127 & Fructokinase $[$ Arachis hypogaea $]$ & 76 & 11 & $20.1 / 5.07$ & $20.6 / 5.27$ \\
\hline 027 & gi|425194 & Heat shock protein $[$ Spinacia oleracea $]$ & 112 & 25 & $70.8 / 5.15$ & $68.6 / 5.50$ \\
\hline 028 & gi|212276328 & Hypothetical protein LOC100191878 [Zea mays] & 82 & 20 & $59.5 / 9.72$ & $55.3 / 6.18$ \\
\hline 029 & gi|224174082 & 4-Coumarate-coa ligase [Populus trichocarpa] & 86 & 14 & $16.6 / 9.03$ & $12.3 / 5.78$ \\
\hline 030 & gi|255618262 & Conserved hypothetical protein [Ricinus communis] & 82 & 12 & $20.3 / 11.86$ & $22.3 / 6.16$ \\
\hline 031 & gi|116055419 & Unnamed protein product [Ostreococcus tauri] & 89 & 22 & $52.5 / 9.06$ & $50.7 / 5.96$ \\
\hline 032 & gi| 115486767 & Os11g0701800 & 87 & 11 & $33.9 / 9.33$ & $35.1 / 6.21$ \\
\hline 033 & gi|79325139 & Glycine-rich protein [Arabidopsis thaliana] & 77 & 16 & $60.5 / 5.28$ & $72.2 / 5.33$ \\
\hline
\end{tabular}

SC: spot coverage. 
Glycine-rich protein (GRP, spot 033), an important structural protein present in plant cell walls [14], and Se-wap41, a protein involved in cell wall polysaccharide synthesis [15], were not expressed in the etiolated branches. This indicates that etiolation may interfere with cell wall formation.

Methylmalonate-semialdehyde dehydrogenase (MM-ALDH, spot 002), enolase (spot 007), ribulose-1,5-bisphosphate carboxylase (Rubisco) large subunit (spot 011), Mat K (spot 013) and heat shock protein (HSP, spot 027) are involved in plant stress responses. Their expression suggests that etiolation improves the survivability of juvenile branches under stress.

\section{Discussion}

Proteins, as the products of the comprehensive expression of functional genes, directly reflect biological function and impact the growth and development of plants. Through a proteomic comparison of non-etiolated and etiolated cuttings during different rooting periods, we sought to better understand the rooting mechanism of tetraploid $R$. pseudoacacia branches and the response of individual proteins on the basis of their function.

\subsection{Cell Wall Metabolism and Remodeling}

Plant morphogenesis includes mechanisms to control the balance between cell division, cell expansion and cell adhesion [16-18]. In our study, we found two proteins (spots 033 and 023, identified as GRP and Se-wap41, respectively) associated with metabolism and the remodeling of cell walls.

GRP (spot 033), an important structural protein in plant cell walls, was not present in etiolated specimens and was found to be down-regulated. GRP in the cell wall has a structural function and plays a role in bracing and adhesion and in the distribution of other components of the cell wall [19]. GRP also participates in the reparative process of xylem conduit primary walls after passive stretching [20].

Se-wap41 was only expressed in non-etiolated branches. Se-wap41 is a $41-\mathrm{kDa}$ wall-associated protein that was reported to label plasmodesmata in the Golgi and class I reversibly glycosylated polypeptide (RGP) [15]. RGPs are thought to be involved in cell wall polysaccharide synthesis [21-25]. Using immunogold labeling, Dhugga et al. [26] showed that RGP1 was specifically localized to Golgi stacks, where it is likely involved in xyloglucan biosynthesis [27].

According to Ludwig et al. [28], maceration of cell walls where adventitious root primordial formation was in progress was better for the formation of adventitious roots. In a study of adventitious root development in Pinus contorta, Brinker et al. [29] found that during the first 3 days after auxin treatment, genes with the potential to be active in cell wall synthesis undergo down-regulation, and, at the same time, genes involved in weakening cell walls and cell adhesion were up-regulated.

\subsection{Proteins Involved in Carbohydrate Metabolism}

Respiration is critical to metabolism in higher plants: it releases the energy stored in carbon-based compounds, providing it for the organism and for physiological activity.

Fructokinase (FRK) (spot 026) is an important metabolic signaling enzyme and key enzyme in sucrose decomposition [30]. Sucrose can be directly stored or transformed into hexose for storage and for respiratory metabolism. Sucrose is converted to glucose and fructose by invertase and then 
phosphorylated by FRK and hexokinase [31,32]. Sucrose, glucose and fructose greatly stimulate the induction of adventitious roots [33]. Enolase (spot 007) has a role in the Embden-Meyerhof-Parnas pathway (EMP), which responds to many environmental stressors, including salt, drought, cold and hypoxia [34]. The enolase content in maize is increased 1.4 times during stress [20]. Enolase appeared only in etiolated branches in this study (day 9). The EMP pathway provides large amounts of carbohydrates for the Krebs cycle [35], and its product, pyruvic acid, is very active and indirectly participates in the regulation of adventitious root development through various metabolic pathways [36].

Spot 011 (Rubisco large subunit) is the catabolite of Rubisco. Rubisco is a key enzyme in $\mathrm{CO}_{2}$ fixation during photosynthesis and is involved in photorespiration in plants [37]. As one of the main organic nitrogen compounds in plants, Rubisco is related to the uptake and utilization of nitrogen [37]. Under stressful conditions, Rubisco is prone to degradation, ultimately inhibiting photosynthesis [38], while low degradation rates for Rubisco are beneficial for the formation of adventitious roots [36]. Spot 011 appeared only in non-etiolated plants (day 0 ).

\subsection{Proteins Involved in Metabolism}

4-Coumarate-CoA ligase (4CL) (spot 029) is a key lignin synthesis enzyme, the last enzyme in phenylpropyl derivative metabolism and an important enzyme in the divergent synthetic pathway of natural phenylpropyl derivatives [39]. 4CL activity is associated with the plant lignin content and with the contents of cinnamic aldehyde and $\mathrm{S}$ residues in lignin molecules. The lignin content should decrease when 4CL activity is restricted [40-42]. Cho [43] found that indole-3-butyric acid (IBA)-treated Cinnamomum kanehirae cuttings had lower amounts of lignin and exhibited greater induction of adventitious roots. 4CL only appeared during adventitious root primordium formation (day 3) in non-etiolated branches. We speculate that through a decrease in lignin, etiolated branches produce more root primordia during the formation of adventitious roots.

MM-ALDH (spot 002) is encoded by a single gene, ALDH6B2, in A. thaliana. MM-ALDH is associated with the degradation of valine to propionyl coenzyme A, but this enzyme is not well studied and its expression has not been clarified [44]. Currently, studies of ALDH have mainly focused on abiotic stress [45,46]. Gao et al. [47] found that genes from eight ALDH gene families $(2,3,5,7,10$, 11,18 and 22) responded to drought and salt stress. Chen et al. [48] found that BADH (ALDH gene family 10) was able to oxidize betaine aldehyde to betaine, which maintains the osmotic balance of plant cells and enhances plant stress resistance. MM-ALDH was up-regulated, especially on day 0 , and may be the result of stress during the early cutting period.

\subsection{Transcription, Translation and Signal Transduction}

Mat K (spot 013) participates in shearing the introns of type II chloroplast RNA transcripts, thereby influencing the expression of regulatory genes [49]. Jia et al. [50] speculated that when Mat K and other chloroplast genes are up-regulated, metabolic disorders of the chloroplast result, leading to bud death. They conjectured that programmed cell death may be a physiological phenomenon commonly occurring when plants abort buds, age and are under stress. Mat K was only present during the initial period (day 0) in non-etiolated branches; in comparison, it was weakly expressed in etiolated ones. 
The higher chlorophyll content in non-etiolated branches may be a reason for this differential expression pattern or it may be due to stress during the cutting process.

Ribosomal protein S4 (spot 006) is a ribosomal protein that functions in protein synthesis. In mammals, ribosomal protein S4 is located at the junction of the 40S and 60S subunits and interacts with initiation factor Eif-3 [51]. Ribosomal protein S4 may be related to the interaction between mRNAs and ribosomes [51]. We know little about the relationships between ribosomal protein S4 and the structure-function of ribosomes in plants. Ribosomal protein S4 has only been cloned in potato and cotton. The up-regulation of ribosomal protein S4 may increase mRNA expression, thereby promoting the formation of adventitious roots.

Spot 001 corresponds to an RNA-binding protein belonging to a large protein family containing DNA and RNA recognition sequences and involved in regulating the alternative splicing of RNA. They also play an important role in regulating transcriptional processing, translation and RNA metabolism [52,53]. Spot 001 was highly expressed in non-etiolated branches and may be associated with the strong metabolic activity of non-etiolated branches. The 54-kDa signal recognition particle (SRP, spot 003) is a chloroplast signal recognition protein. The SRP plays an important role in the transport of endoplasmic reticulum-secreted proteins to the cell membrane. It contains SRP 7S RNA and six proteins, including a 54-kDa protein signal receiver (SRP54) identifying the original polypeptide signal sequence and a 19-kDa signal receiving protein that adheres to the SPR 7S RNA directly, which is important in the recognition and binding of the SPR54 particle [54]. Both secreted proteins and membrane proteins have a target receptor signal sequence. The SRP identifies the signal sequence in the initial polypeptide sequence, binding and extending the polypeptide sequence [55-57].

\subsection{Protein Metabolism}

HSP (spot 006) has been widely studied, especially for its functions in stress. HSP is normally expressed in the cytoplasm of cell bodies and axons, where it binds to and stabilizes microtubules, promoting the solubility of proteins and protein binding to microtubules [58]. In our study, HSP was up-regulated in etiolated branches. Up-regulated HSP helps maintain the functions of many proteins, sustaining normal physiological function.

Actin is an important protein generally present in eukaryotic cells and involved in many activities. Actin is a single polypeptide chain of globular proteins (G-actin) consisting of 375-377 amino acids. Actin is an important component of the plant cytoskeleton and microfilaments and contributes to cell elongation, probably through interactions with cortical microtubules [59]; it also maintains polar auxin transport [60]. Spots 004 and 020 were identified as actin. In our study, we found that on days 0 and 3 the expression of the two actin proteins were not obviously different between the etiolated samples and controls, but on day 9 the expression in the controls was very low. Day 9 marks the period of adventitious root elongation, and the weak expression of actin has a negative influence on the elongation of adventitious roots. 


\section{Experimental Section}

\subsection{Chemicals and Reagents}

Tris, octylphenoxypolyethoxyethanol (NP-40), urea, sulfourea, 3-[(3-Cholamidopropyl)dimethylammonio]1-propanesulfonate (CHAPS), sodium dodecyl sulphate (SDS), acrylamide, $N, N$ '-methylenebisacrylamide, ammonium persulfate, $N, N, N^{\prime}, N^{\prime}$-tetramethylethylene diamine, CBB G-250 and trichloroacetic acid were obtained from Amresco (Solon, OH, USA); phenylmethylsulfonyl fluoride was obtained from Sigma (St. Louis, MO, USA); immobilized pH gradient strips (IPG strips, $17 \mathrm{~cm}, \mathrm{pH} \mathrm{4-7)} \mathrm{and}$ iodoacetamide were obtained from Bio-Rad Laboratories (Hercules, CA, USA); acetone, glycerol, phosphoric acid, carbinol and alcohol (analytical reagents) were obtained from manufacturers in China. All water used in this experiment was Milli-Q hyperpure water (Millipore, Billerica, MA, USA).

\subsection{Plant Materials}

Non-etiolated and etiolated juvenile branch cuttings of tetraploid $R$. pseudoacacia $\mathrm{K} 4$ clones [treated with $2000 \mathrm{mg} / \mathrm{L}$ indole-3-butyric acid (IBA) before cutting] at different stages of rooting [callus induction (day 0), adventitious root primordium formation (day 3), and adventitious root elongation] were collected from Lucun National Forest Farm (Luoning, Henan, China) in the spring. Phloem from a branch $2 \mathrm{~cm}$ from the base was stripped using a knife and placed immediately in liquid nitrogen.

\subsection{Protein Extraction}

Total protein extracts were prepared according to the method of Wang et al. [10] with minor modifications. A total of $2 \mathrm{~g}$ of powdered phloem were suspended in $6 \mathrm{~mL}$ of cold extraction solution ( $10 \%$ trichloroacetic acid in acetone containing $0.07 \% \beta$-mercaptoethanol) and then incubated at $-20{ }^{\circ} \mathrm{C}$ for $6 \mathrm{~h}$. The samples were then centrifuged at $13,000 \times \mathrm{g}$ for $25 \mathrm{~min}$ at $4{ }^{\circ} \mathrm{C}$ and the supernatant was discarded. The last step was repeated 2-3 times. The pellet was dried under a vacuum for $10 \mathrm{~min}$ at $4{ }^{\circ} \mathrm{C}$ and stored at $-70{ }^{\circ} \mathrm{C}$.

The dried pellet was dissolved in lysis buffer containing $8 \mathrm{M}$ urea, $2 \mathrm{M}$ thiourea, 4\% CHAPS, $60 \mathrm{mM}$ dithiothreitol (DTT) and 0.5\% IPG buffer $(\mathrm{pH}=4.7)$, then oscillated on an oscillator for $2 \mathrm{~min}$, incubated at $28{ }^{\circ} \mathrm{C}$ in a water bath for $30 \mathrm{~min}$ and then centrifuged at $13,000 \times \mathrm{g}$ for $30 \mathrm{~min}$ at room temperature. The protein concentration of the supernatant was determined by the Bradford method.

\subsection{Two-Dimensional Electrophoresis (2-DE)}

Two-dimensional gel electrophoresis was performed in accordance with the Bio-Rad handbook. A total of $1.3 \mathrm{mg}$ of sample was loaded onto analytical and preparative gels. For isoelectric focusing, the Bio-Rad

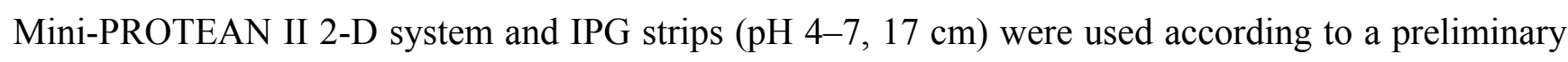
experiment. The IPG strips were rehydrated for $12 \mathrm{~h}$ in $350 \mu \mathrm{L}$ of rehydration buffer containing protein.

The gel strips were equilibrated twice for $15 \mathrm{~min}$ each with $10 \mathrm{~mL}$ of the following equilibration buffers: (i) reducing buffer for $15 \mathrm{~min}(0.373 \mathrm{M}$ Tris-HCl buffer, $\mathrm{pH} 8.8,6 \mathrm{M}$ urea, 20\% v/v glycerol, $2 \% \mathrm{w} / v$ SDS and $0.2 \mathrm{~g}$ of DTT); and (ii) alkylating buffer for $15 \mathrm{~min}(0.373 \mathrm{M}$ Tris-HCl buffer, $\mathrm{pH} 8.8,6 \mathrm{M}$ urea, 20\% $v / v$ glycerol, $2 \% w / v$ SDS and $2.5 \mathrm{~g}$ of iodoacetamide). SDS-PAGE was 
performed on $12 \%$ gels using the PROTEAN II xi cell system (Bio-Rad Laboratories). The gels were run for $0.5 \mathrm{~h}$ at $5 \mathrm{~mA}$ per gel, then at $20-30 \mathrm{~mA}$ per gel until the dye front reached the gel bottom. The proteins were stained with CBB G-250.

\subsection{Image Acquisition and Data Analysis}

Two-dimensional electrophoresis images were obtained using a Scanner GS-800 (Bio-Rad Laboratories) in transmission mode. Image analysis was done using a combination of manual visualization and software calculations with PDQuest Gel Analysis Software (Bio-Rad Laboratories). All 2-DE images were globally analyzed by the software for spots that significantly differed in a comparison of the different rooting periods.

\subsection{Trypsin Digestion}

The CBB-stained spots were excised from the gels and destained for 30 min until the gel was transparent using a destaining solution containing 50\% acetonitrile (ACN) and $25 \mathrm{mM}$ ammonium bicarbonate $\left(\mathrm{NH}_{4} \mathrm{HCO}_{3}\right)$.

The gels were dried for 30 min using the Thermo Savant Speed-Vac system. A total of $3 \mathrm{~mL}$ of trypsin solution (final concentration $10 \mathrm{ng} / \mu \mathrm{L}$ dissolved in $25 \mathrm{mM} \mathrm{NH}_{4} \mathrm{HCO}_{3}$ ) were pipetted onto each dried protein spot and the sample was incubated at $4{ }^{\circ} \mathrm{C}$ for $1 \mathrm{~h}$. The supernatant was discarded and the Ep tubes were placed upside down and incubated at $37^{\circ} \mathrm{C}$ for $15 \mathrm{~h}$. To extract the peptide fragments from the trypsin digest, $50 \mu \mathrm{L}$ of $5 \%(v / v)$ trifluoroacetic acid (TFA) were added to the samples and incubated at $40{ }^{\circ} \mathrm{C}$ for $1 \mathrm{~h}$. Next, the supernatant was transferred to another clean Ep tube. A total of $50 \mu \mathrm{L}$ of $50 \%(v / v)$ ACN [containing $2.5 \%(v / v)$ TFA] were added to the gel and the samples were incubated at $30{ }^{\circ} \mathrm{C}$ for $1 \mathrm{~h}$. The supernatant was collected and dried in a Speed-Vac system then stored at $4{ }^{\circ} \mathrm{C}$.

\subsection{Protein Identification by MALDI-TOF/TOF-MS}

The digested peptides were desalted and cleaned with ZipTip C18 pipette tips (Millipore Corp., Bedford, MA, USA) before obtaining the mass spectrum of the peptide mixture. All analyses were performed using a Bruker Daltonics Autoflex (Bruker Daltonics, Billerica, MA, USA) operated at $350 \mathrm{~nm}$ Nd YAG with an accelerating voltage of $20 \mathrm{kV}$. The peptide mixture was analyzed using a saturated solution of $R$-cyano-4-hydroxycinnamic acid in $50 \%$ ACN/0.1\% TFA. External calibration was performed with peptides from myoglobin and internal calibration with trypsin autoproteolytic fragments. The samples were analyzed on a MALDI-TOF/TOF-MS 4700 proteomics analyzer (Agilent Technologies, Santa Clara, CA, USA) and the data were analyzed using MASCOT software (Matrix Science, London, UK).

\section{Conclusions}

In our study, tetraploid $R$. pseudoacacia juvenile branches were subjected to etiolation followed by a proteomic analysis of treated and control samples in different rooting periods. A total of fourteen etiolation-responsive proteins were successfully identified (Table 1) by 2-DE and MALDI-TOF/TOF-MS. Proteins are the most direct reflection of plant etiolation responses. Through 
further analysis, we can determine the possible roles for the fourteen proteins in promoting the rooting of juvenile branches. These differentially expressed proteins should be the focus of future studies. The real factor responsible for the higher rooting rate in etiolated juvenile branches might be found among them. More work needs to be done on these proteins, including comparing them with etiolation-responsive proteins in other species to determine if any of them are shared. In our future work, we plan to compare the expression between etiolated and non-etiolated juvenile tetraploid $R$. pseudoacacia branches at the transcriptome level during different rooting periods, through which we hope to find the genes associated with rooting. If we can confirm the significant proteins and genes and determine the mechanism of the higher rooting rate in juvenile etiolated tetraploid $R$. pseudoacacia branches, it would improve the cutting technology of tetraploid $R$. pseudoacacia trees.

\section{Acknowledgments}

The authors appreciate the financial support from the National Natural Science Foundation of China (No. 31170629); the National Science and Technology Support Program (No. 2012BAD01B0601); and the Program for Changjiang Scholars and Innovative Research Team in University (No. IRT13047).

\section{Author Contributions}

Data analysis and paper writing: Nan Lu. Protein identification: Zhaohe $\mathrm{Xu}$. Two-dimensional electrophoresis: Bingnan Meng. Protein extraction and Sample preparation: Yuhan Sun. Plant materials preparation: Jiangtao Zhang, Shaoming Wang and Yun Li.

\section{Conflicts of Interest}

The authors declare no conflict of interest.

\section{References}

1. Li, Y.; Jiang, J.Z. Research progress of feed tetraploid black locust. Pratacult. Sci. 2006, 23, $41-46$.

2. Zhang, G.J.; Li, Y.; He, C.C. Nutrition and growth of leaves at different leaf ages in tetraploid Robinia pseudoacacia. Sci. Silvae Sin. 2009, 45, 61-67.

3. Dong, Z.; Yue, S.M.; Sui, Z.Y. Tetraploid black locust breeding by using root nutrition bags. J. Hebei For. Sci. Technol. 2008, 3, 60.

4. Shang, Z.H. Research on the rapid propagation technology of tetraploid Robinia pseudoacacia. J. Anhui Agric. Sci. 2008, 36, 2315-2316.

5. Meng, B.N.; Peng, Z.D.; Zhang, Z.L.; Xu, H.M.; Li, Y. Research on cuttage of tetraploid black locust (Robinia pseudoacacia L.) hardwood treated by low temperature sand storage and plant growth regulator. Heilongjiang Agric. Sci. 2010, 8, 85-88.

6. Yang, X.F.; Cao, B.H.; Li, S.B.; Ren, Y.H. Studies on the hard stem cutting propagation technique of Robinia pseudoacacia L. Shandong For. Sci. Technol. 2007, 2, 50-51.

7. Frolich, E.F.; Platt, R.G. Use of the etiolation technique in rooting avocado cuttings. Calif. Avocado Soc. 1971, 55, 97-109. 
8. Hansen, O.B.; Potter, J.R. Rooting of apple, rhododendron, and mountain laurel cuttings from stock plants etiolated under two temperatures. HortScience 1997, 32, 304-306.

9. Richards, M.R.; Rupp, L.A. Etiolation improves rooting of bigtooth maple cuttings. HortTechnology 2012, 22, 305-310.

10. Li, J.H. The Principle and Application of Cutting; Shanghai Science and Technology Press: Shanghai, China, 1987; pp. 10-12.

11. Lu, N.; Meng, B.N.; Sun, Y.H.; Li, Y.; Wang, S.M.; Guo, Z.M.; Wang, Q.L.; Xu, H.M. Dynamic of physiology and biochemistry during etiolated shoots cutting of tetraploid Robinia pseudoacacia. J. Northeast. For. Univ. 2013, 11, 5-9.

12. Konishi, H.; Yamane, H.; Maeshima, M.; Komatsu, S. Characterization of fructose-bisphosphate aldolase regulatedby gibberellin in roots of rice seedling. Plant Mol. Biol. 2004, 56, 839-848.

13. Sorin, C.; Negroni, L.; Balliau, T.; Corti, H.; Jacquemot, M.P.; Davanture, M.; Sandberg, G.; Zivy, M.; Bellini, C. Proteomic analysis of different mutant genotypes of Arabidopsis led to the identification of 11 proteins correlating with adventitious root development. Plant Physiol. 2006, 140, 349-364.

14. Wang, W.; Scali, M.; Vignani, R.; Spadafora, A.; Sensi, E.; Mazzuca, S.; Cresti, M. Protein extraction for two-dimensional electrophoresis from olive leaf, a plant tissue containing high levels of interfering compounds. Electrophoresis 2003, 24, 2369-2375.

15. Ringli, C.; Keller, B.; Ryser, U. Glycine-rich proteins as structural components of plant cell walls. Cell. Mol. Life Sci. 2001, 58, 1430-1441.

16. Sagi, G.; Katz, A.; Guenoune-Gelba, D.; Epel, B.L. Class 1 reversibly glycosylated polypeptides are plasmodesmal-associated proteins delivered to plasmodesmata via the Golgi apparatus. Plant Cell 2005, 17, 1788-1800.

17. Silk, W.K. Steady form from changing cells. Int. J. Plant Sci. 1992, 153, S49-S58.

18. Beemster, G.T.; Baskin, T.I. Analysis of cell division and elongation underlying the developmental acceleration of root growth in Arabidopsis thaliana. Am. Soc. Plant Biol. 1998, 116, 1515-1526.

19. Beemster, G.T.; Baskin, T.I. Stunted plant 1 mediates effects of cytokinin, but not of auxin, on cell division and expansion in the root of Arabidopsis. Plant Physiol. 2000, 12, 1718-1727.

20. Showalter, A.M. Structure and function of plant cell wall proteins. Plant Cell 1993, 5, 9-23.

21. Darvill, A.; McNeil, M.; Albersheim, P. The primary cell walls of flowering plants. In The Biochemistry of Plants; Academic Press: New York, NY, USA, 1980; Volume 9, p. 91.

22. Hayashi, T. Xyloglucans in the primary cell wall. Ann. Rev. Plant Biol. 1989, 40, 139-168.

23. Brummell, D.A.; Camirand, A.; Maclachlan, G. Differential distribution of xyloglucan glycosyl transferases in pea Golgi dictyosome and secretory vesicles. J. Cell Sci. 1990, 96, 705-710.

24. Driouich, A.; Faye, L.; Staehelin, L.A. The plant Golgi apparatus: A factory for complex polysaccharides and glycoproteins. Trends Biochem. Sci. 1993, 18, 210-214.

25. Staehelin, L.; Moore, I. The plant Golgi apparatus structure, functional organization and trafficking mechanisms. Annu. Rev. Plant Physiol. 1995, 46, 261-288.

26. Dhugga, K.S.; Tiwari, S.C.; Ray, P.M. A reversibly gly-cosylated polypeptide (RGP1) possibly involved in plant cell wall synthesis: Purification, gene cloning, and trans-Golgi localization. Proc. Natl. Acad. Sci. USA 1997, 94, 7679-7684.

27. Sherrier, D.J.; VandenBosch, K.A. Secretion of cell wall polysaccharides in Vicia root hairs. Plant J. 1994, 5, 185-195. 
28. Ludwig-Müller, J.; Vertocnik, A.; Town, C.D. Analysis of indole-3-butyric acid-induced adventitious root formation on Arabidopsis stem segments. J. Exp. Bot. 2005, 56, 2095-2105.

29. Brinker, M.; Zyl, L.V.; Liu, W.B.; Craig, D.; Sederoff, R.R.; Clapham, D.H.; Arnold, S.V. Microarray analyses of gene expression during adventitious root development in Pinus contorta. Plant Physiol. 2004, 135, 1526-1539.

30. Qin, Q.P.; Zhang, S.L.; Chen, J.W.; Wu, J.Y.; Chen, K.S. The relationship of fructokinase and sugar accumulation during fruit development in satsuma mandarin. J. Plant Physiol. Mol. Biol. 2004, 30, 435-440.

31. Pego, J.V.; Smeekens, S. Plant fructokinases: A sweet family get-together. Trends Plant Sci. 2000, 5, 531-536.

32. Williams, L.E.; Lemoine, R.; Sauer, N. Sugar transporters in higher plants a diversity of roles and complex regulation. Trends Plant Sci. 2000, 5, 283-290.

33. Fumio, T.; Kumi, S.N.; Kazutaka, K.; Mitsuo, S.; Hitoshi, S. Sugar-induced adventitious roots in Arabidopsis seedlings. J. Plant Res. 2003, 116, 83-91.

34. Forsthoefel, N.R.; Cushman, M.; Cushman, J.C. Posttranscriptional and posttranslational control of enolase expression in the facultative Crassulacean acid metabolism plant Mesembryanthemum crystallinum L. Plant Physiol. 1995, 108, 1185-1195.

35. Wasaki, J.; Yonetan, R.; Kuroda, S. Transcriptomic analysis of metabolic changes by phosphorus stress in rice plant roots. Plant Cell Environ. 2003, 26, 1515-1523.

36. Han, H.; Zhang, S.G.; Sun, X.M. A review on the molecular mechanism of plants rooting modulated by auxin. Afr. J. Biotechnol. 2009, 8, 348-353.

37. Ghannoum, O.; Evans, J.R.; Chow, W.S.; Andrews, T.J.; Conroy, J.P.; Caemmerer, S.V. Faster Rubisco is the key to superiornitrogen-use efficiency in NADP-malic enzyme relative to NAD-malic enzyme C4 grasses. Plant Physiol. 2005, 137, 638-650.

38. Medrano, H.; Parry, M.A.J.; Socias, X.; Lawlor, D.W. Long term water stress inactivates RuBisCO in submediterranean clover. Ann. Appl. Biol. 1997, 131, 491-501.

39. Wei, J.H.; Song, Y.R. Recent advances in study of lignin biosynthesis and manipulation. Acta Bot. Sin. 2001, 43, 771-779.

40. Kajita, S.; Katayama, Y.; Omori, S. Alterations in the biosynthesis of lignin in transgenic plants with chimeric genes for 4-coumarate: Coenzyme A ligase. Plant Cell Physiol. 1996, 37, 957-965.

41. Kajita, S.; Hishiyama, S.; Tomimura, Y.; Omori, S. Structural characterization of modified lignin in transgenic tobacco plants in which the activity of 4-coumarate: Coenzyme A ligase is depressed. Plant Physiol. 1997, 11, 871-879.

42. Lee, D.; Meyer, K.; Chapple, C.; Douglas, C.J. Antisense suppression of 4-coumarate: Coenzyme A ligase activity in Arabidopsis leads to altered lignin subunit composition. Plant Cell Online 1997, 9, 1985-1998.

43. Cho, H.Y.; Chang, C.Y.; Huang, L.C.; Tsai, J.B.; Liu, Z.H. Indole-3-butyric acid suppresses the activity of peroxidase while inducing adventitious roots in Cinnamomum kanehirae. Bot. Stud. 2011, 52, 153-160.

44. Steele, M.I.; Lorenz, D.; Hatter, K.; Park, A.; Sokatch, J.R. Characterization of the mmsAB operon of Pseudomonas aeruginosa PAO encoding ethylmalonate-semialdehyde dehydrogenase and 3-hydroxyisobutyrate dehydrogenase. J. Biol. Chem. 1992, 267, 13585-13592. 
45. Kirch, H.H.; Bartels, D.; Wei, Y.; Schnable, P.S.; Wood, A.J. The $A L D H$ gene superfamily of Arabidopsis. Trends Plant Sci. 2004, 9, 371-377.

46. Kirch, H.H.; Nair, A.; Bartels, D. Novel ABA-and dehydration-inducible aldehyde dehydrogenase genes isolated from the resurrection plant Craterostigma plantagineum and Arabidopsis thaliana. Plant J. 2001, 28, 555-567.

47. Gao, C.; Han, B. Evolutionary and expression study of the aldehyde dehydrogenase $(A L D H)$ gene superfamily in rice (Oryza sativa). Gene 2009, 431, 86-94.

48. Chen, X.; Zeng, Q.; Wood, A.J. The stress-responsive Tortula ruralis gene ALDH21A1 describes a novel eukaryotic aldehyde dehydrogenase protein family. J. Plant Physiol. 2002, 159, 677-684.

49. Vogel, J.; Hubsehman, T.; Borner, T.; Hess, W.R. Splicing and intron-internal RNA editing of trnK-matK transcripts in barley plastids: Support for MatK as an essential splice factor. J. Mol. Biol. 1997, 270, 179-187.

50. Jia, J.; Zhang, L.G. mRNA differential display and Est sequence analysis of aborted bud and normal bud in Radishi (Raphanus sativus). J. Nucl. Agric. Sci. 2008, 22, 426-431.

51. Westermann, P.; Nygard, O. The spatial arrangement of the complex between eukaryotic initiation factor eIF-3 and 40S ribosomal sub-unit. Biochim. Biophys. Acta 1983, 741, 103-108.

52. Cheng, J.; Li, K.; Lu, Y.Y.; Wang, L.; Liu, Y. Bioinformatics analysis of human hepatitis C virus core protein-binding protein 6 gene and protein. World Chin. J. Digestol. 2003, 11, 378-384.

53. Chen, X.; Li, W.Z.; Shao, Y.; Zeng, Q.C. Progress in RNA-binding proteins in animals and plants. Biotechnol. Bull. 2007, 3, 9-15.

54. Walter, P.; Lingappa, V.R. Mechanism of protein translocation across the endoplasmic reticulum membrane. Ann. Rev. Cell Biol. 1986, 2, 499-516.

55. Wolin, S.L.; Waiter, P. Signal recognition particle mediates a transient elongation arrest of preprolaetin in reticulocyte lysate. J. Cell Biol. 1989, 109, 2617-2622.

56. Meyer, E.I.; Krause, E.; Dobberstein, B. Secretory protein translocation across membranes: The role of the "docking protein". Nature 1982, 297, 647-650.

57. Rǒmisch, K.; Webb, J.; Lingelbach, K.; Gausepohl, H.; Dobberstein, B. The 54-kD protein of signal recognition particle contains a methionine-rich RNA binding domain. J. Cell Biol. 1990, $111,1793-1802$.

58. Li, Q.B.; Haskell, D.W.; Guy, C.L. Coordinate and noncoordinate expression of the stress 70 family and other molecular chaperones at high and low temperature in spinach and tomato. Plant Mol. Biol. 1999, 39, 21-34.

59. Collins, J.F.; Pawloski, D.C.; Davis, M.G.; Ball, N.; Dorn, G.W.; Walsh, R.A. The role of the cytoskeleton in left ventricular pressure overload hypertrophy and failure. J. Mol. Cell. Cardiol. 1996, 28, 1435-1443.

60. Reed, R.C.; Brady, S.R.; Muday, G.K. Inhibition of auxin movement from the shoot into the root inhibits lateral root development in Arabidopsis. Plant Physiol. 1998, 118, 1369-1378.

(C) 2014 by the authors; licensee MDPI, Basel, Switzerland. This article is an open access article distributed under the terms and conditions of the Creative Commons Attribution license (http://creativecommons.org/licenses/by/3.0/). 